\title{
Persoalan Pengaturan Kewajiban Pemegang Paten untuk Membuat Produk atau Menggunakan Proses di Indonesia
}

\author{
Muh Ali Masnun dan Dina Roszana \\ Universitas Negeri Surabaya \\ Jl. Ketintang, Ketintang, Kec. Gayungan, Surabaya, Jawa Timur 60231 \\ alimasnun@unesa.ac.id; dinaroszana@gmail.com
}

Received: 26 Mei 2019; Accepted: 10 Juli 2019; Published: 22 Agustus 2019

DOI: 10.20885 /iustum.vol26.iss2.art6

\begin{abstract}
The regulation of the obligation to implement patents by patent holders to create products or use of the processes in Indonesia is still relatively problematic. For example, the Regulation of the Ministry of Law and Human Rights No. 15 of 2018 concerning the Use of Patents by Patent Holders (Permenkumham No. 15 of 2018), actually negates Article 20 of Law No.13 of 2016 concerning Patents (2016 Patent Law). This study examines and evaluates the issue of regulating the obligations of patent holders to create products or the use of processes in Indonesia. This research uses the normative juridical method by using secondary data. The results of the study concluded that the 2016 Patent Law and Permenkumham No. 15 of 2018 as a basis for its implementation is still relatively short and has several weaknesses. Such as the unclarity of when the patent starts, the scope and type of patents that must be implemented, the implementation delay is not accompanied by criteria (reasons) whether or not a delay can be made, the time limit for submitting the application for a delay that does not pay attention to the duration of patent protection, the absence of anticipatory provisions to overcome the conditions of delay request rejection from the Ministry, as well as arrangements for the extension of the delay that is not paired with a deadline and criteria for the extention allowance.
\end{abstract}

Keywords: Creating products; patent regulation; use of process

Abstrak

Pengaturan kewajiban pelaksanaan paten oleh pemegang paten untuk membuat produk atau menggunakan proses di Indonesia masih relatif mengandung persoalan. Sebagai contohnya, Peraturan Menteri Hukum dan Hak Asasi Manusia Nomor 15 Tahun 2018 tentang Pelaksanaan Paten oleh Pemegang Paten (Permenkumham No. 15 Tahun 2018), justru menegasikan Pasal 20 Undang-Undang Nomor 13 Tahun 2016 tentang Paten (UU Paten 2016). Penelitian ini mengkaji dan mengevaluasi persoalan pengaturan kewajiban pemegang paten untuk membuat produk atau menggunakan proses di Indonesia. Penelitian ini menggunakan metode yuridis normatif, dengan menggunakan data sekunder. Hasil penelitian menyimpulkan bahwa UU Paten 2016 dan Permenkumham No. 15 Tahun 2018 sebagai dasar pelaksanaannya masih relatif sumir dan memiliki beberapa kelemahan. Beberapa kelemahan tersebut yaitu belum jelasnya waktu dimulainya pelaksanaan paten, lingkup dan jenis paten yang wajib dilaksanakan, pengaturan penundaan pelaksanaan yang tidak disertai dengan kriteria (alasan) dapat atau tidaknya dilakukan penundaan, pengaturan batas waktu pengajuan permohonan penundaan yang tidak memerhatikan durasi pelindungan paten, tidak adanya ketentuan antisipatif untuk mengatasi kondisi apabila permohonan penundaan tidak disetujui oleh Menteri, serta pengaturan perpanjangan penundaan yang tidak disertai dengan batas waktu dan kriteria dapat atau tidaknya dilakukan perpanjangan penundaan.

Kata-kata Kunci: Pengaturan; paten; membuat produk; menggunakan proses 


\section{Pendahuluan}

Manusia dianugerahi oleh sang Kuasa berupa akal pikiran, sehingga memiliki kemampuan dalam hal mendayagunakan intelektualitasnya dengan menghasilkan berbagai kreativitas berupa ciptaan, desain maupun invensi di bidang ilmu pengetahuan, teknologi dan bisnis. Luaran dari intelektualitas manusia tersebut lazim dikenal dengan Kekayaan Intelektual (KI). Apabila KI telah memiliki pelindungan hukum berupa hak eksklusif yang diberikan oleh negara kepada pencipta, pendesain, atau inventor, maka akan menjadi hak kekayaan intelektual (HKI) yang telah diakui dan diatur secara internasional melalui perjanjian, konvensi internasional, traktat, maupun secara nasional melalui berbagai peraturan perundang-undangan di bidang HKI.

Indonesia telah mengakui pelindungan HKI meliputi bidang hak cipta, merek, rahasia dagang, desain industri, desain tata letak sirkuit terpadu, serta paten sebagai implikasi atas ratifikasi perjanjian internasional melalui Undang-Undang Nomor 7 Tahun 1994 tentang Pengesahan Agreement Establishing the World Trade Organization (Persetujuan Pembentukan Organisasi Perdagangan Dunia). Pelindungan HKI di bidang paten berupa hak eksklusif yang diberikan kepada inventor merupakan salah satu bentuk penghargaan atas jerih payah berupa pikiran, tenaga, maupun biaya yang telah dikeluarkan. Perkembangan teknologi yang sangat pesat pada saat ini turut memengaruhi berbagai bidang, baik bidang ekonomi, sosial budaya, dan juga hukum. ${ }^{1}$ Paten sebagai salah satu jenis HKI di bidang teknologi memiliki peran penting dan strategis dalam pembangunan Indonesia, terutama dalam merangsang pertumbuhan ekonomi, yang dapat dilakukan melalui 4 cara berikut: ${ }^{2}$

1. Informasi paten memudahkan alih teknologi dan investasi;

2. Paten mendorong penelitian dan pengembangan pada universitasuniversitas dan pusat-pusat studi penelitian;

3. Paten sebagai katalisator untuk teknologi baru dan bisnis;

4. Bisnis menghimpun dan menggunakan paten dalam rangka pemberian lisensi, usaha bersama dan transaksi-transaksi lain yang menghasilkan keuntungan.

Hal di atas memberikan catatan penting bagi semua elemen masyarakat dan pemerintah mengenai pentingnya paten bagi sebuah negara. Apalagi Indonesia

\footnotetext{
${ }^{1}$ Rindia Fanny, "Reformasi Peraturan Paten di Indonesia", Makalah Seminar, Semarang, 2016, hlm. 3

${ }^{2}$ Kamil Idris, Kekayaan Intelektual Sebuah Kekuatan Untuk Pertumbuhan Ekonomi, Direktorat Jenderal Hak Kekayaan Intelektual, Departemen Kehakiman dan Hak Asasi Manusia Republik Indonesia, Jakarta, 2000, hlm. 10
} 
sebagai negara berkembang yang notabene perlu akselerasi pembangunan dalam segala bidang agar tidak selalu mengekor kepada negara-negara maju. Akselerasi yang dilakukan oleh Indonesia salah satunya menerapkan kewajiban bagi pemegang Paten untuk membuat produk ataupun menggunakan proses di Indonesia. Ketentuan berkaitan dengan hal tersebut diatur dalam Undang-Undang Nomor 13 Tahun 2016 tentang Paten (UU Paten 2016).

Pasal 20 UU Paten 2016 menyatakan bahwa pemegang paten wajib membuat produk atau menggunakan proses di Indonesia. Ketentuan ini mengandung maksud bahwa pemegang paten baik dari dalam negeri maupun luar negeri yang telah mengajukan permohonan dan telah mendapat perlindungan paten (granted) dari Indonesia berkewajiban untuk membuat produk atau proses di Indonesia. Selain itu juga ada keharusan untuk menunjang transfer teknologi, penyerapan investasi dan/atau penyediaan lapangan kerja. Ketentuan tersebut jika dilihat dari politik hukum, ${ }^{3}$ tampak ada arah yang jelas mengenai formulasi pengaturan pelaksanaan paten oleh pemegang paten bagi kemandirian dan kemajuan teknologi di Indonesia tanpa harus memiliki ketergantungan terhadap impor luar negeri.

Formulasi ketentuan Pasal 20 UU Paten 2016 ini cukup menjadi perhatian kalangan akademisi, praktisi, swasta (asing) maupun pemerintah baik pada saat pembahasan Rancangan Undang-Undang (RUU) di Dewan Perwakilan Rakyat (DPR) maupun pasca pengundangan UU Paten 2016. Praktisi sekaligus konsultan HKI Suyud Margono menilai bahwa ketentuan Pasal 20 UU Paten 2016 tidak seharusnya ada, jika pun ada justru akan sulit diterapkan pada tataran teknisnya. ${ }^{4}$ Kamar Dagang Amerika juga salah satu pihak yang merasa keberatan jika ketentuan tersebut benar-benar diterapkan mengingat ketentuan tersebut dinilai diskriminasi dan bertentangan dengan Article 27 TRIPs Agreement yang berbunyi, patents shall be available and patent rights enjoyable without discrimination as to the place of invention, the field of technology and whether products are imported or locally produced. ${ }^{5}$ Belum lagi

\footnotetext{
${ }^{3}$ Moh Mahfud MD, Membangun Politik. Hukum, Menegakekan Konstitusi, Rajawali Pers, Jakarta, 2010, hlm. 15-16 https:/ / kliklegal.com/wajibkan-pemegang-paten-membuat-produk-di-indonesia-uu-paten-menuaikritik/ diakses 14 Mei 2019

5 Terjemahan bebasnya bahwa paten harus tersedia dan bak paten dinikmati tanpa diskriminasi berkaitan dengan tempat ditemukannya, di bidang teknologi dan apakah produk tersebut diimpor atau diproduksi di tingkat lokal.
} 
mengenai nasib inventor dalam negeri jika invensinya akan dilisensikan ke negara lain, dan negara lain menerapkan aturan sebagaimana yang diatur di Indonesia.

Ada beberapa pihak yang setuju dengan tetap berlakunya Pasal 20 UU Paten 2016 dengan beberapa pertimbangan. Ketua Pansus RUU Paten John Kenedy Azis mengungkapkan:

"bahwa pelaksanaan paten oleh pemegang paten merupakan inisiatif dari pemerintah dan disetujui oleh anggota dewan, karena memiliki 3 tujuan. Pertama, aturan itu berfungsi untuk mengukur kualitas barang yang dihasilkan, khususnya mengenai kesesuaiannya dengan yang didaftarkan. Kedua, ketentuan itu secara otomatis dapat membuka lapangan pekerjaan yang dapat menyerap tenaga kerja Indonesia. Ketiga, investasi yang datang ke Indonesia juga akan semakin banyak, atau pemasukan lain seperti pajak dan lain sebagainya."6

Hal senada disampaikan Ranggalawe Suryasaladin, yang mengungkapkan bahwa kehadiran Pasal 20 UU Paten 2016 salah satu fokusnya adalah untuk transfer teknologi.7 Lebih lanjut Ranggalawe mengungkapkan, bahwa kewajiban pemegang paten untuk membuat produk di Indonesia sebenarnya sudah diatur dalam UU Paten sebelumnya, yakni UU No. 14 Tahun 2001 tentang Paten.8 Oleh karena itu jika ada pengaturan kewajiban pemegang paten membuat produk atau menggunakan proses di Indonesia tidak perlu menjadi polemik berkepanjangan.

Terkait pro dan kontra ketentuan Pasal 20 UU Paten 2016, pihak pemerintah dalam hal ini Menteri Hukum dan Hak Asasi Manusia (Menkumham) telah menyiapkan alternatif solusi, yaitu dibentuknya pranata hukum yang lebih teknis melalui Peraturan Menteri Hukum dan Hak Asasi Manusia Nomor 15 Tahun 2018 tentang Pelaksanaan Paten oleh Pemegang Paten (Permenkumham No. 15 Tahun 2018), sebagai peraturan pelaksanaan Pasal 20 UU Paten 2016. Jika dicermati secara seksama, justru terdapat beberapa materi muatan yang cenderung kontradiktif dan sumir, pertama, Permenkumham No. 15 Tahun 2018 terkesan menegasikan semangat yang sudah diatur dalam Pasal 20 UU Paten 2016. Kedua, belum ada kepastian hukum mengenai batas penundaan tidak melaksanakan kewajiban

\footnotetext{
${ }^{6}$ https://kliklegal.com/ini-alasan-dpr-wajibkan-pemegang-paten-membuat-produk-diindonesia/?relatedposts_hit=1\&relatedposts_origin=778\&relatedposts_position=1 Diakses 14 Mei 2019 https://kliklegal.com/akademisi-fhui-menilai-pasal-20-uu-paten-berguna-untuk-transfer-teknologi/ diakses tanggal 29 Mei 2019

8 Ibid.
} 
pemegang paten dan ketiga secara tersirat formulasi ketentuannya lebih pro kepada kepentingan luar negeri daripada kepentingan dalam negeri.

Tabel. 1

Pengaturan Pelaksanaan Paten oleh Pemegang Paten Berdasarkan Permenkumham No. 15 Tahun 2018

\begin{tabular}{|c|c|c|c|}
\hline No & Pasal & Hal/Substansi & Keterangan \\
\hline 1 & Pasal 1 & Ketentuan umum & Sesuai dengan UU Paten 2016 \\
\hline 2 & Pasal 2 & $\begin{array}{lr}\text { Kewajiban } & \text { membuat } \\
\text { produk } & \text { atau } \\
\text { menggunakan } & \text { proses di } \\
\text { Indonesia } & \end{array}$ & $\begin{array}{l}\text { Sama dengan Pasal } 20 \text { UU Paten 2016, } \\
\text { meskipun ketentuan tersebut } \\
\text { membuka ruang/celah karena tidak/ } \\
\text { belum memberi batasan yang jelas. }\end{array}$ \\
\hline 3 & Pasal 3 & $\begin{array}{l}\text { Penundaan pelaksanaan } \\
\text { pembuatan produk atau } \\
\text { proses paling lama } 5 \\
\text { (lima) tahun dengan } \\
\text { pengajuan permohoan } \\
\text { kepada Menteri dengan } \\
\text { disertai alasan. }\end{array}$ & $\begin{array}{l}\text { 1. Cenderung menegasikan Pasal } 20 \\
\text { UU Paten 2016; } \\
\text { 2. Belum mencerminkan arah } \\
\text { pembangunan dan penguasaan } \\
\text { teknologi di Indonesia; } \\
\text { 3. Belum disertai alasan-alasan yang } \\
\text { rigid sebagai menjadi dasar } \\
\text { penundaan pelaksanaan pembuatan } \\
\text { produk atau proses. }\end{array}$ \\
\hline 4 & Pasal 4 & $\begin{array}{l}\text { Permohonan penundaan } \\
\text { pelaksanaan paling lama } \\
3 \text { (tiga) tahun sejak } \\
\text { tanggal pemberian paten. }\end{array}$ & $\begin{array}{l}\text { Belum menjangkau pengaturan terkait } \\
\text { dengan paten yang telah memeroleh } \\
\text { sertifikat lebih dari } 3 \text { (tiga) tahun. }\end{array}$ \\
\hline 5 & Pasal 5 & $\begin{array}{l}\text { Dalam hal disetujui oleh } \\
\text { Menteri, penundaan } \\
\text { pelaksanaan } \\
\text { diberitahukan } \\
\text { Pemegang Paten } \\
\text { kepada }\end{array}$ & $\begin{array}{l}\text { Belum diatur konsekuensi hukum } \\
\text { apabila penundaan pelaksanaan paten } \\
\text { tidak disetujui oleh Menteri. }\end{array}$ \\
\hline 6 & Pasal 6 & $\begin{array}{l}\text { Penundaan pelaksanaan } \\
\text { paten dapat diperpanjang } \\
\text { dengan disertai alasan }\end{array}$ & $\begin{array}{l}\text { 1. Belum ditentukan mengenai batas } \\
\text { frekuensi perpanjangan dapat } \\
\text { dilakukan; } \\
\text { 2. Alasan yang dapat digunakan } \\
\text { sebagai dasar penundaan juga } \\
\text { masih sangat sumir. }\end{array}$ \\
\hline
\end{tabular}

\section{Rumusan Masalah}

Berdasarkan uraian di atas maka dapat dirumuskan isu hukum dalam penelitian ini adalah bagaimana persoalan pengaturan kewajiban pemegang paten untuk membuat produk atau menggunakan proses di Indonesia? 


\section{Tujuan Penelitian}

Penelitian ini mengkaji dan mengevaluasi persoalan pengaturan kewajiban pemegang paten untuk membuat produk atau menggunakan proses di Indonesia yang hingga saat ini masih cukup menjadi polemik di kalangan akademisi, praktisi, maupun swasta.

\section{Metode Penelitian}

Penelitian ini menggunakan metode yuridis normatif atau kepustakaan hukum doktrinal yang dapat diartikan sebagai penelitian hukum dengan cara mengkaji penerapan norma-norma atau kaidah-kaidah dalam hukum positif. Konsep ini memandang hukum sebagai suatu sistem normatif yang bersifat mandiri, tertutup dan terlepas dari kehidupan masyarakat yang nyata. ${ }^{9}$ Pendekatan yang digunakan dalam penelitian ini adalah pendekatan perundangundangan, pendekatan historis, dan pendekatan konseptual. Teknik pengumpulan bahan hukum dilakukan dengan studi kepustakaan (library research), dengan cara mengumpulkan, mengolah, menafsirkan dan membandingkan bahan-bahan hukum yang dinilai relevan dengan permasalahan yang akan ditulis. Bahan hukum yang terkumpul akan dianalisis secara dekskriptif kualitatif.

\section{Hasil Penelitian dan Pembahasan}

Indonesia sebagai negara berkembang memiliki potensi Sumber Daya Alam (SDA) dan Sumber Daya Manusia (SDM). Sebagai negara kepulauan (darat dan laut), SDA Indonesia begitu melimpah. Sedangkan dari sisi SDM, jumlah penduduk sekitar 250 juta jiwa juga merupakan bonus demografi, baik dari sisi tenaga kerja maupun pasar di bidang ekonomi yang cukup menarik bagi negaranegara maju. Berkaitan dengan SDA di Indonesia, saat ini relatif masih banyak yang belum dieksplorasi maupun dieksploitasi, jika pun ada eksplorasi dan eksploitasi, namun relatif banyak yang dilakukan oleh asing. Hal ini senada dengan yang disampaikan oleh Achmad Zen Umar Purba, bahwa pemanfaatan SDA yang ada di tanah air kita yang kaya itu sebenarnya "kaya"dari sudut potensi, $13-14$.

${ }_{9}^{9}$ Ronny Hanitijo Soemitro, Metodologi Penelitian Hukum dan Jurimetri, Ghalia Indonesia, Jakarta, 1988, hlm. 
bukan riil, hanya tergantung pada keahlian atau pengetahuan SDM asing. ${ }^{10}$ Keahlian ataupun pengetahuan yang dimiliki asing tidak terlepas dari teknologi yang mereka hasilkan, dengan teknologi akan berdampak terhadap berbagai bidang kehidupan. Sri Redjeki Hartono mengungkapkan bahwa abad 19 atau 20, teknologi telah mengubah tatanan kehidupan manusia, dan yang paling terasa adalah dalam dunia ekonomi. ${ }^{11}$

Paten tidak hanya berkaitan dengan segi teknologi (technological interest) tapi juga berkaitan dengan ekonomi dan investasi (economical interest), bahkan dapat menjadi bargaining position bagi suatu negara dalam melakukan ekspor impor komoditinya. ${ }^{12} \mathrm{Hal}$ ini menjadi salah satu komoditi yang memiliki nilai besar bagi negara-negara maju seperti Jepang, USA, Korea, Jerman karena telah mengekspor teknologinya ke negara-negara berkembang. Negara tersebut tidak memiliki SDA yang melimpah sebagaimana di negara berkembang (termasuk Indonesia), tetapi memiliki teknologi yang dihasilkan oleh SDM mereka dan teknologi itulah yang dibutuhkan oleh negara berkembang untuk mengelola atau mengolah SDAnya. Teknologi memiliki peran yang sangat penting bagi pembangunan nasional suatu negara, khususnya bagi negara berkembang. Kesadaran menggunakan teknologi untuk mengembangkan kemampuan negara dalam perekonomian dan peningkatan kualitas hidup masyarakat telah mendorong berbagai negara berkembang dengan mengikutsertakan ilmu pengetahuan dan teknologi dalam pembangunan nasionalnya. ${ }^{13}$

Bermunculan mitos di berbagai negara berkembang bahwa industrialisasi merupakan salah satu jalan pintas untuk menuju kemajuan dalam pembangunan ekonomi guna menyejahterakan masyarakat. ${ }^{14}$ Berbagai upaya dilakukan dengan maksud agar tidak mengalami ketergantungan dan selalu mengekor teknologi yang telah dihasilkan oleh negara-negara maju, karena negara berkembang harus

${ }^{10}$ Achmad Zen Umar Purba, "Peta Mutakhir Hak Kekayaan Intelektual di Indonesia", Jurnal Hukum dan Pembangunan, Januari-Maret 2012, hlm. 26

${ }^{11}$ Sri Redjeki Hartono, Kapita Selekta Hukum Ekonomi, Mandar Maju, Bandung, 2000, hlm. 19

${ }^{12}$ Endang Purwaningsih, "Paten Sebagai Konstruksi Hukum Perlindungan Terhadap Invensi dalam Bidang Teknologi dan Industri”, Jurnal Hukum Pro Justitia, 2006, hlm. 130

${ }^{13}$ Sabartua Tampubolon, Politik Hukum Iptek di Indonesia, Jogjakarta: Kepel Press, 2013, hlm. 84

${ }^{14}$ Retna Gumanti, "Perjanjian Lisensi di Indonesia", Jurnal Al Mizan IAIN Gorontalo, Vol. 12, 2016, hlm. 
membayar mahal. Sebagaimana diungkapkan Dewi Astuty Mochtar bahwa ketergantungan teknologi membawa dampak antara lain:15

1) Membayar dengan harga tinggi pembelian teknologi tersebut;

2) Tidak mampu untuk melaksanakan kontrol terhadap industri-industri yang dibangun;

3) Tidak akan berhasil mengembangkan "indigenous technological capability".

Sejarah perkembangan konsep HKI melalui perjalanan yang relatif panjang, karena memang tumbuh dan berkembang seiring dengan peradaban manusia. Italia adalah negara pertama yang memiliki UU HKI pada tahun 1474, hingga akhirnya berkembang sampai ada beberapa konvensi internasional (Paris Convention dan Bern Convention) yang menjadi tonggak pengakuan pelindungan HKI secara internasional.

Perkembangan pelindungan kekayaan intelektual semakin pesat dalam tatanan internasional dan menjadi salah satu isu pada globalisasi saat ini, khususnya sejak disepakati perjanjian internasional tentang Agreement Trade Related Aspect of Intellectual Property Rights (TRIPs Agreement) sebagai salah satu pilar perjanjian World Trade Organization (WTO) yang dihasilkan pada tahun 1986 di Uruguay Round dan telah diratifikasi oleh 150 lebih negara termasuk Indonesia. ${ }^{16}$

Sejarah terbentuknya TRIPs dilandasai oleh keinginan negara industri kapitalis untuk menguasai pasar ekonomi dunia dengan memaksakan berlakunya aturan standar hak milik intelektual di negara berkembang. ${ }^{17}$

Terminologi HKI secara definitif sulit ditemukan dalam peraturan perundang-undangan di Indonesia, sehingga istilah Hak Kekayaan Intelektual (HKI) dimaknai secara berbeda-beda oleh para ahli. Perbedaan pemaknaan atas HKI tidak mengurangi substansi bahwa HKI merupakan hak eksklusif yang diberikan oleh negara kepada pencipta, inventor, atau pendesain atas kreativitas yang dihasilkan dengan mendayagunakan intelektualitasnya. Para ahli mengklasifikasikan HKI ke dalam hukum harta kebendaan karena memiliki sifat-

\footnotetext{
15 Dewi Astutty Mochtar, Perjanjian Lisensi Alih Teknologi dalam Pengembangan Teknologi Indonesia, Alumni, Bandung, 2001, hlm. 58

${ }^{16}$ Kholis Roisah, Konsep Hukum Hak Kekayaan Intelektual (Sejarah, Pengertian, dan Filosofi HKI dari Masa ke Masa), Setara Press, Malang, 2015, hlm. 2

${ }^{17}$ Endang Purwaningsih, Paten Sebagai Konstruksi..., Op. Cit., hlm. 133
} 
sifat kebendaan dan dapat dimiliki secara absolut (hak mutlak), ${ }^{18}$ dengan ciri hak tersebut dapat dijual, dilisensikan, diwariskan atau mekanisme pengalihan hak yang lain.

Apapun berbagai definisi yang diformulasikan oleh para ahli, HKI selalu dikaitkan dengan 3 unsur penting antara lain:

1) Adanya hak eksklusif yang diberikan oleh hukum;

2) Hak tersebut dikaitkan dengan usaha manusia yang didasarkan pada kemampuan intelektual;

3) Kemampuan intelektual tersebut memiliki nilai ekonomi. ${ }^{19}$

HKI diklasifikasikan menjadi hak cipta dan hak milik industri. Hak milik industri terdiri atas paten, merek, desain industri, rahasia dagang, dan desain tata letak sirkuit terpadu yang masing-masing memiliki karakteristik khas. Paten merupakan salah satu jenis hak milik industri yang berkaitan dengan bidang teknologi dan menjadi perhatian banyak negara berkembang untuk dapat di optimalkan. Istilah "paten" yang digunakan saat ini dalam peraturan perundangundangan merupakan istilah pengganti octrooi yang berasal dari bahasa Belanda, sementara istilah octrooi berasal dari bahasa latin auctor. Paten sendiri merupakan kata yang diserap dari bahasa Inggris yaitu patent. Bahasa latin kata auctor memiliki makna "dibuka", merupakan suatu penemuan yang mendapatkan paten menjadi terbuka untuk diketahui oleh umum. Paten yang memiliki sifat terbuka, bukan berarti setiap orang bisa mempraktikkan penemuan tersebut, melainkan penemuan tersebut dapat didayagunakan oleh orang lain setelah habis masa pelindungan patennya dan menjadi milik umum (public domain). ${ }^{20}$

Paten sebagai hak eksklusif yang diberikan oleh negara kepada inventor tidak diberikan secara tanpa batas, tetapi negara dapat intervensi memberikan pengaturan yang sifatnya pembatasan. Eksploitasi hak eksklusif melalui HKI (paten) yang berlebihan dapat menimbulkan ketidakadilan sosial (social unjust). ${ }^{21}$ Kepentingan umum dalam pelindungan HKI dapat dibenarkan secara filosofis

18 Dadan Samsudin, Hak Kekayaan Intelektual dan Manfaatnya Bagi Lembaga Litbang, Direktorat Jenderal Kekayaan Intelektual Kementerian Hukum dan Hak Asasi Manusia, 2016, hlm. 1

19 Tomy Suryo Utomo, Hak Kekayaan Intelektual di Era Global, Graha Ilmu, Yogyakarta, 2010, hlm. 2

${ }^{20}$ Endang Purwaningsih, Perkembangan Hukum Intellectual Property Right: Kajian Hukum terhadap Hak atas Kekayaan Intelektual dan Kajian Komparatif Hukum Paten, Ghalia Indonesia, Bogor, 2005, hlm. 157 hlm. 41

${ }^{21}$ Winner Sitorus, "Kepentingan Umum dalam Perlindungan Paten”, Jurnal Yuridika, Vol. 29 No. 1, 2014, 
dengan prinsip keadilan, maksudnya bahwa ketentuan pelindungan HKI (paten) dalam bentuk hak eksklusif harus memberi keseimbangan antara kepentingan

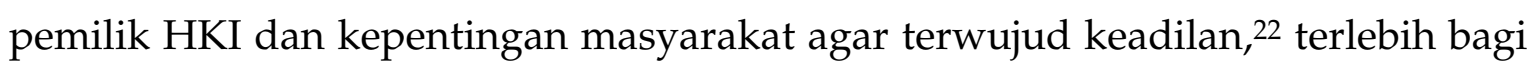
negara-negara berkembang yang memiliki keterbatasan kemampuan dalam mengakses dan memanfaatkannya.

Justifikasi secara yuridis terkait pembatasan hak eksklusif paten demi kepentingan umum juga telah diberikan melalui Article 7 TRIPs, yang menentukan bahwa:

"The protection and enforcement of intellectual property rights should contribute to the promotion of technological innovation and to the transfer and dissemination of technology, to the mutual advantage of producers and users of technological knowledge and in a manner conducive to social and economic welfare, and to a balance of rights and obligations"

Secara eksplisit bahwa pelindungan dan penegakan HKI harus dapat memberikan manfaat bagi inovasi, alih teknologi, dan diseminasi teknologi dengan memerhatikan kepentingan yang seimbang antara penghasil dan pengguna teknologi dengan mendukung kesejahteraan sosial dan ekonomi serta menyeimbangkan hak dan kewajiban.

Asas-asas atau prinsip yang dianut dan mendasari pengaturan pelindungan UU Paten 2016 dapat menjadi dasar pelaksanaan paten untuk kepentingan umum. Adapun asas-asas tersebut antara lain:23

1. Asas Manfaat, maksudnya bahwa perlindungan paten yang memberikan manfaat bagi para inventor pemegang hak dan pengguna hak paten.

2. Asas Rasional, maksudnya bahwa pelindungan paten yang mempertimbangkan nilai ekonomis dari invensi, berdasarkan sifat alamiah dari perkembangan pengetahuan manusia itu sendiri, mempertimbangkan ketahanan nasional, kesejahteraan masyarakat dan keadilan bagi seluruh komponen masyarakat.

3. Asas Berkelanjutan maksudnya bahwa pengelolaan hak yang memerhatikan perkembangan teknologi dan sosiologi agar pemanfaatannya dapat diteruskan dalam waktu mendatang.

4. Asas Berkeadilan, maksudnya bahwa pelindungan paten yang menjamin aksesibilitas informasi seluruh lapisan masyarakat.

5. Asas Kesejahteraan Masyarakat, maksudnya bahwa pelindungan paten yang berorientasi pada kesejahteraan seluruh lapisan masyarakat.

${ }^{22}$ Ibid., hlm. 46

${ }^{23}$ Enny Nurbaningsih, Naskah Akademik RUU tentang Paten, Badan Pembinaan Hukum Nasional, Jakarta, 2015, hlm. 25-26 
Pengaturan pelaksanaan kewajiban yang melekat kepada pemegang paten untuk membuat produk atau menggunakan prosesnya tidak baru saja ada ketika UU Paten 2016. Ketentuan pelaksanaan paten oleh paten di Indonesia telah berkembang dari masa ke masa, mulai UU Paten 1989 sampai dengan UU Paten 2016 telah mengaturnya. Indonesia telah melaksanakan sistem paten melalui UU Paten 1989, karena sebelum berlakunya UU tersebut, Indonesia (Hindia Belanda) menggunakan Octroi Wet 1910 yang lebih pro kepada Pemerintah Kolonial Hindia Belanda karena setiap temuan (sekarang invensi) sistem pendaftarannya harus melalui Pemerintah di Belanda. Meskipun demikian, Pasal 18 UU Paten 1989 telah mengakomodasi ketentuan kewajiban pemegang paten untuk melaksanakan patennya di wilayah Negara Republik Indonesia.

Pasal 82 UU Paten 1989, memuat ketentuan jika pemegang paten tidak melaksanakan patennya sebagaimana Pasal 18, maka setelah jangka waktu 36 bulan terhitung sejak tanggal pemberian paten, setiap orang dapat mengajukan lisensi wajib kepada pengadilan negeri untuk melaksanakan paten tersebut. Secara tersirat, jika dilihat dari politik hukum bahwa ketentuan kewajiban pelaksanaan paten bagi pemegang paten sudah baik, dengan asumsi bahwa pembentuk undang-undang sudah memikirkan arah atau kebijakan di bidang paten untuk penguasaan teknologi bangsa Indonesia tanpa perlu ketergantungan dengan asing.

Lahirnya Undang-Undang Nomor 13 Tahun 1997 tentang Perubahan Atas Undang-Undang Nomor 6 Tahun 1989 Tentang Paten (UU Paten 1997) merupakan perubahan atas UU Paten 1989 untuk mengakomodasi beberapa ketentuan TRIPs yang belum diatur sebelumnya. Berkaitan dengan ketentuan Pasal 18 UU Paten 1997 tidak ada perubahan signifikan, hanya menambahkan pada ayat (2) dan ayat (3) dalam bentuk pengecualian jika pelaksanaan paten tersebut secara ekonomi hanya layak apabila dibuat dengan skala regional dengan disertai alasan dan bukti serta disetujui oleh Kantor Paten. Pasal 82 juga turut ditambahkan berkaitan dengan pengajuan lisensi wajib yang dimungkinkan jika pemegang paten melaksanakan paten tersebut dengan cara merugikan kepentingan masyarakat.

Diundangkannya Undang-Undang No. 14 Tahun 2001 tentang Paten (UU Paten 2001) menggantikan secara keseluruhan UU Paten 1989 dan UU Paten 1997. Berkaitan dengan ketentuan pelaksanaan kewajiban pemegang paten diatur dalam 
Pasal 17 UU Paten 2001, bahwa ada klausul kewajiban membuat produk dan menggunakan proses di Indonesia dengan ada tambahan pengecualian jika pembuatan dan proses tersebut hanya layak dilakukan secara regional dengan syarat mendapat persetujuan dari Direktorat Jenderal Kekayaan Intelektual (DJKI) dan disertai alasan berikut buktinya. Jika mencermati perubahan tersebut, sekali lagi penyusun UU Paten 2001 lebih mengkonkritkan pada "pembuatan produk dan prosesnya". Hal demikian tentu harapan yang begitu besar dengan adanya paten dari luar negeri yang dapat dimanfaatkan maupun dikembangkan oleh inventor dalam negeri.

UU Paten 2016 sebagai UU terbaru di bidang Paten menggantikan secara keseluruhan UU Paten 2001. Lahirnya UU tersebut diantaranya untuk menstimulasi peningkatan permohonan paten nasional/domestik dan meningkatkan peran negara untuk melindungi kesejahteraan dan keselamatan rakyatnya melalui pemanfaatan paten. Hal tersebut termuat dalam ketentuan pelaksanaan paten oleh pemegang paten yang diatur dalam Pasal 20 UU Paten 2016 yang relatif sama, tetapi pengecualian sebagaimana UU Paten 2001 ditiadakan. Pasal 20 ayat (2) UU Paten 2016 lebih memberikan ketegasan bahwa pelaksanaan tersebut harus menunjang transfer teknologi, penyerapan investasi, dan/atau penyediaan lapangan kerja.

Pengaturan sebagaimana disebut di atas merupakan bukti keseriusan pemerintah untuk benar-benar dapat memanfaatkan paten secara optimal, terlebih jika ketentuan tersebut tidak dilaksanakan maka gugatan penghapusan paten dimungkinkan menurut UU Paten 2016 melalui mekanisme gugatan ke Pengadilan Niaga oleh jaksa atau pihak lain yang memiliki kepentingan nasional, atau penerima lisensinya. Jika ada pihak yang tidak setuju terhadap ketentuan yang terkait dengan Pasal 20 UU Paten 2016 tentu cukup aneh, sebab dalam konteks ini pemerintah menunjukkan keseriusan dan ketegasannya atas paten yang terdaftar di Indonesia. Sehingga sangat wajar apabila harus memberikan manfaat bagi rakyat Indonesia secara umum. Secara sederhana ruang lingkup pengaturan pelaksanaan paten tersaji pada tabel berikut. 
Tabel. 2

Transformasi Pengaturan Pelaksanaan Paten oleh Pemegang Paten

\begin{tabular}{|c|c|c|c|}
\hline No & Regulasi & Ketentuan & Keterangan \\
\hline \multirow[t]{2}{*}{1} & $\begin{array}{l}\text { UU } \\
\text { Paten }\end{array}$ & Pasal 18 & $\begin{array}{l}\text { Pemegang Paten wajib melaksanakan patennya di } \\
\text { wilayah Negara Republik Indonesia. }\end{array}$ \\
\hline & 1989 & Pasal 82 & $\begin{array}{l}\text { (1) Setiap orang setelah lewat jangka waktu tiga puluh } \\
\text { enam bulan terhitung sejak tanggal pemberian } \\
\text { paten, dapat mengajukan permintaan Lisensi Wajib } \\
\text { kepada Pengadilan Negeri untuk melaksanakan } \\
\text { paten yang bersangkutan. } \\
\text { (2) Permintaan Lisensi Wajib sebagaimana dimaksud } \\
\text { dalam ayat (1) hanya dapat dilakukan dengan } \\
\text { alasan bahwa paten yang bersangkutan tidak } \\
\text { dilaksanakan di Indonesia oleh Pemegang Paten } \\
\text { padahal kesempatan untuk melaksanakannya } \\
\text { secara komersial sepatutnya ditempuh. }\end{array}$ \\
\hline \multirow[t]{4}{*}{2} & $\begin{array}{l}\text { UU } \\
\text { Paten }\end{array}$ & $\begin{array}{l}\text { Pasal } 18 \\
\text { ayat }(1)\end{array}$ & $\begin{array}{l}\text { Pemegang Paten wajib melaksanakan patennya di } \\
\text { wilayah Negara Republik Indonesia. }\end{array}$ \\
\hline & 1997 & $\begin{array}{l}\text { Pasal } 18 \\
\text { ayat (2) }\end{array}$ & $\begin{array}{l}\text { Dikecualikan dari kewajiban sebagaimana dimaksud } \\
\text { dalam ayat (1) apabila pelaksanaan paten tersebut secara } \\
\text { ekonomi hanya layak bila dibuat dengan skala regional. }\end{array}$ \\
\hline & & $\begin{array}{l}\text { Pasal } 18 \\
\text { ayat (3) }\end{array}$ & $\begin{array}{l}\text { Pengecualian sebagaimana dimaksud dalam ayat (2) } \\
\text { hanya dapat disetujui Kantor Paten apabila diajukan } \\
\text { dengan permintaan tertulis oleh pemegang paten } \\
\text { dengan disertai alasan dan bukti-bukti yang diberikan } \\
\text { oleh instansi yang berwenang. }\end{array}$ \\
\hline & & $\begin{array}{l}\text { Pasal } 18 \\
\text { ayat }(4)\end{array}$ & $\begin{array}{l}\text { Syarat-syarat mengenai pengecualian dan tata cara } \\
\text { pengajuan permintaan tertulis sebagaimana dimaksud } \\
\text { dalam ayat (3) diatur lebih lanjut dengan Peraturan } \\
\text { Pemerintah. }\end{array}$ \\
\hline \multirow[t]{4}{*}{3} & $\begin{array}{l}\text { UU } \\
\text { Paten }\end{array}$ & $\begin{array}{l}\text { Pasal } 17 \\
\text { ayat }(1)\end{array}$ & $\begin{array}{l}\text { Pemegang Paten wajib membuat produk atau } \\
\text { menggunakan proses yang diberi Paten di Indonesia. }\end{array}$ \\
\hline & 2001 & $\begin{array}{l}\text { Pasal } 17 \\
\text { ayat }(2)\end{array}$ & $\begin{array}{l}\text { Dikecualikan dari kewajiban sebagaimana dimaksud } \\
\text { pada ayat (1) apabila pembuatan produk atau } \\
\text { penggunaan proses tersebut hanya layak dilakukan } \\
\text { secara regional. }\end{array}$ \\
\hline & & $\begin{array}{l}\text { Pasal } 17 \\
\text { ayat (3) }\end{array}$ & $\begin{array}{l}\text { Pengecualian sebagaimana dimaksud pada ayat (2) } \\
\text { hanya dapat disetujui oleh Direktorat Jenderal apabila } \\
\text { Pemegang Paten telah mengajukan permohonan } \\
\text { tertulis dengan disertai alasan dan bukti yang } \\
\text { diberikan oleh instansi yang berwenang. }\end{array}$ \\
\hline & & $\begin{array}{l}\text { Pasal } 17 \\
\text { ayat }(4)\end{array}$ & $\begin{array}{l}\text { Syarat-syarat mengenai pengecualian dan tata-cara } \\
\text { pengajuan permohonan tertulis sebagaimana } \\
\text { dimaksud pada ayat (3) diatur lebih lanjut dengan } \\
\text { Peraturan Pemerintah. }\end{array}$ \\
\hline
\end{tabular}




\begin{tabular}{llll}
\hline 4 UU & Pasal 20 & Pemegang Paten wajib membuat produk atau \\
Paten & ayat (1) & menggunakan proses di Indonesia. & \\
& Pasal 20 & $\begin{array}{l}\text { Membuat produk atau menggunakan proses } \\
\text { ayat (2) } \\
\end{array}$ & $\begin{array}{l}\text { sebagaimana dimaksud pada ayat (1) harus menunjang } \\
\text { transfer teknologi, penyerapan investasi dan / atau } \\
\text { penyediaan lapangan kerja. }\end{array}$ \\
\hline
\end{tabular}

Justifikasi untuk melegitimasi bahwa Pasal 20 UU Paten 2016 tidak seharusnya ada, bertentangan dengan TRIPs, atau sulit untuk diterapkan sebenarnya tidak terlalu mendasar. Pertama, bahwa HKI (Paten) sebagai hak eksklusif bagi inventor tidak dapat diberlakukan secara sepenuhnya. Eksploitasi hak eksklusif melalui HKI (paten) yang berlebihan dapat menimbulkan ketidakadilan sosial (social unjust). ${ }^{24}$ Indonesia sebagai negara berkembang harus dapat memanfaatkan secara optimal paten yang telah didaftarkan di Indonesia, ketika paten tersebut telah dilaksanakan di Indonesia dengan melakukan pengembangan, modifikasi, atau inovasi atas invensi yang telah ada. Jika kembali ke belakang bahwa lahirnya TRIPs adalah kepentingan negara maju yang digunakan untuk melindungi komoditi merek, namun demikian jika komoditi dilakukan secara eksploitatif maka menurut penulis tidak baik bagi Indonesia yang notabene masih memiliki keterbatasan untuk itu.

Kedua, bahwa asas-asas atau prinsip yang dianut dan mendasari pengaturan pelindungan dalam UU Paten dapat menjadi dasar pelaksanaan paten untuk kepentingan umum. Asas manfaat, asas rasional, asas berkelanjutan, asas berkeadilan, dan asas kesejahteran adalah asas yang dapat menjadi justifikasi bahwa memang sudah sepantasnya jika pemegang paten melaksanakan patennya di Indonesia dan harus memberikan manfaat melalui alih teknologi, investasi, atau penyerapan tenaga kerja. ${ }^{25}$ Masalah bagi negara berkembang adalah keperluan akan teknologi untuk pembangunan ekonominya, sedangkan bagi negara-negara maju merupakan kepentingan dalam perluasan pasar dari teknologi atau hasil industrinya. ${ }^{26}$ Perbedaan kepentingan dan kedudukan ini yang akan menghambat

\footnotetext{
${ }^{24}$ Winner Sitorus, Kepentingan Umum dalam..., Op. Cit., hlm. 41

${ }^{25}$ Enny Nurbaningsih, Naskah Akademik RUU..., Op. Cit., hlm. 25

${ }^{26}$ OK Saidin, Aspek Hukum Hak Kekayaan Intelektual (Intellectual Property Right), Raja Grafindo Persada, 2013, Jakarta, hlm. 314
} 
terjadinya akselerasi pembangunan di negara berkembang, dan pada akhirnya negara berkembanglah yang akan dirugikan atas kepentingan negara maju.

Ketiga, penilaian yang menyatakan bahwa Pasal 20 UU Paten 2016 bertentangan dengan Article 27 TRIPs dapat terjawab dengan alasan pertama dan kedua terkait pembatas eksploitasi dan beberapa prinsip/asas. Terlebih bahwa Article 7 TRIPs menentukan HKI (Paten) harus dapat memberikan manfaat bagi inovasi, alih teknologi, dan diseminasi teknologi dengan memperhatikan kepentingan yang seimbang antara penghasil dan pengguna teknologi dengan mendukung kesejahteraan sosial dan ekonomi serta menyeimbangkan hak dan kewajiban.

Kesulitan menerapkan ketentuan ini memang berpotensi terjadi, hal ini dikarenakan Pasal 20 UU Paten 2016 yang relatif masih sangat sumir. Kesumiran yang paling signifikan adalah belum adanya kepastian hukum mengenai batas waktu bagi para pemegang paten untuk membuat produk atau menggunakan prosesnya di Indonesia. Pelaksanaan paten sebagaimana dimaksud dalam UU Paten adalah kewajiban yang melekat kepada pemegang paten untuk membuat produk atau menggunakan proses di Indonesia. Namun, ketentuan ini kemudian dituangkan dalam Permenkumham No. 15 Tahun 2018 yang masih memiliki beberapa kelemahan, sehingga perlu dilakukan pencermatan dan analisis untuk memudahkan pelaksanaan paten oleh pemegang paten di Indonesia. Adapun hal yang melatarbelakangi lahirnya Permenkumhan No. 15 Tahun 2018 disampaikan Menteri Hukum dan Hak Asasi Manusia, Yassona H Laoly bahwa "Pemerintah Indonesia membuat terobosan guna mengatasi keberatan dari pemilik paten di luar negeri soal kewajiban melaksanakan patennya di Indonesia". ${ }^{27}$ Alasan yang melatarbelakangi dibentuknya Permenkumhan No. 15 Tahun 2018 sebagaimana disampaikan Yassona H Laoly tersebut menurut penulis kurang argumentatif.

Permenkumham No. 15 Tahun 2018 ini justru menunjukkan keberpihakan Pemerintah terhadap kepentingan inventor asing, padahal ada kepentingan yang lebih besar bagi kemajuan bangsa Indonesia, utamanya terkait pengalihan teknologi, penyerapan tenaga kerja, maupun investasi. Hal ini diperkuat hasil kajian yang tertuang dalam Naskah Akademik UU Paten 2016, bahwa Undang-

\footnotetext{
${ }^{27}$ https://www.kk-advocates.com/wp-content/uploads/pemilik-paten-dari-luar-negeri-bisa-tundalaksanakan-paten-indonesia.pdf diakses 6 Agustus 2019.
} 
Undang Paten yang telah dilaksanakan sejak 1991, belum berpengaruh signifikan terhadap peningkatan permohonan paten dalam negeri, karena belum dilaksanakan secara efektif oleh para peneliti, baik dari kalangan swasta maupun pemerintah. ${ }^{28}$ Semangat lahirnya UU Paten 2016 ini semestinya dilaksanakan secara konsisten, dan tidak kemudian justru dibentuk peraturan pelaksana yang menegasikan semangat peraturan di atasnya.

Berikut ini tabel analisis penulis mengenai sejumlah kesumiran dan kelemahan yang termuat dalam Permenkumham No. 15 Tahun 2018, disertai perbandingannya dengan Pasal 20 UU Paten 2016.

Tabel. 3

Analisis Pengaturan Kewajiban Pemegang Paten untuk Membuat Produk atau Menggunakan Proses di Indonesia

\begin{tabular}{|c|c|c|}
\hline No & Ketentuan & Analisis dan Rekomendasi \\
\hline 1 & $\begin{array}{l}\text { Pasal } 20 \text { UU Paten } \\
2016\end{array}$ & $\begin{array}{l}\text { Politik hukum UU Paten } 2016 \text { salah satunya } \\
\text { "keberpihakan pada kepentingan Indonesia tanpa } \\
\text { melanggar prinsip-prinsip internasional" berkaitan } \\
\text { dengan keinginan Indonesia mandiri secara teknologi, } \\
\text { teknologi merupakan komoditi "seksi" bagi sebuah } \\
\text { negara yang dapat menyumbang pendapatan sebuah } \\
\text { negara. Kewajiban sebagaimana diatur dalam Pasal } 20 \\
\text { UU Paten } 2016 \text { merupakan salah satu cara akselerasi } \\
\text { penguasaan teknologi bagi Indonesia, di samping itu } \\
\text { teknologi juga memiliki pengaruh pada investasi serta } \\
\text { penyerapan tenaga kerja. } \\
\text { Dalam konteks formulasi, ketentuan Pasal } 20 \text { UU Paten } \\
2016 \text { memang berpotensi sulit diterapkan dan } \\
\text { cenderung diabaikan oleh pemegang paten (utamanya } \\
\text { luar negeri). Hal ini dikarenakan, ketentuan tersebut } \\
\text { belum disertai dengan ketentuan mengenai waktu } \\
\text { dimulainya pelaksanaan paten oleh pemegang paten, } \\
\text { serta dalam jenis dan mencakup bidang paten apa saja. } \\
\text { Sehingga perlu di atur formulasi pengaturan secara } \\
\text { pasti mengenai waktu dimulainya pelaksanaan paten, } \\
\text { serta dalam jenis paten apa saja, dan mencakup bidang } \\
\text { paten apa saia. }\end{array}$ \\
\hline 2 & $\begin{array}{l}\text { Permenkumham } \\
\text { No. } 15 \text { Tahun } \\
2018\end{array}$ & $\begin{array}{l}\text { Keluarnya Permenkumham No. } 15 \text { Tahun } 2018 \text {, pada } \\
\text { dasarnya merupakan bentuk solusi yang diberikan oleh } \\
\text { pemerintah atas polemik pro dan kontra Pasal } 20 \text { UU }\end{array}$ \\
\hline
\end{tabular}

${ }^{28}$ Enny Nurbaningsih, Op. Cit., hlm. 4 
Paten setelah mempertimbangkan alternatif solusi lain. Jika ditinjau dari perspektif perundang-undangan. Pertama, bahwa penulis tidak/belum menemukan peraturan delegasi oleh peraturan perundangundangan di atasnya, baik pada tingkat Peraturan Pemerintah, Peraturan Presiden atau pun UndangUndang kepada Permenkumham No. 15 Tahun 2018. Jika pun ada, penyusunan peraturan perundangundangan harus harmonis, baik secara vertikal (atasbawah) maupun horizontal (sejajar). Lahirnya Permenkumham No. 15 Tahun 2018 memang dimungkinkan sepanjang dibentuk berdasarkan kewenangan (Menkumham), hal tersebut sesuai dengan Pasal 8 ayat (2) Undang-Undang Nomor 12 Tahun 2011 tentang Pembentukan Peraturan Perundang-Undangan bahwa "Peraturan perundangundangan sebagaimana dimaksud pada ayat (1) diakui keberadaannya dan mempunyai kekuatan hukum mengikat sepanjang diperintahkan oleh peraturan perundangundangan yang lebih tinggi atau dibentuk berdasarkan kewenangan". Konsiderans Permenkumham No. 15 Tahun 2018 secara tersurat menunjukkan adanya peraturan menteri terkait Organisasi Tata Kelola di Lingkungan Kemenkumham, sehingga lahirnya peraturan tersebut secara hukum dibenarkan. Kedua, bahwa terlepas dari poin pertama, penulis melihat semangat bahwa Permenkumham No. 15 Tahun 2018 dijadikan sebagai pedoman (guidance) pelaksanaan paten oleh pemegang paten. Meskipun demikian, jika ketentuan tersebut untuk melaksanakan Pasal 20 UU Paten 2016, pengaturan dalam Permenkumham No. 15 Tahun 2018 relatif masih sangat sumir dan perlu ditinjau kembali sebagaimana akan dielaborasi secara mendalam pada bagian bawah ini.

3 Penundaan Kewajiban untuk melaksanakan paten oleh pemegang pelaksanaan paten merupakan langkah strategis akselerasi pembuatan penguasaan teknologi di Indonesia, namun demikian produk atau semangat tersebut belum diikuti dengan infrastruktur menggunakan maupun suprastruktur yang memadai. Sehingga misi proses paling pelaksanaan paten berpotensi tidak dapat lama lima 5 direalisasikan dengan baik.

(tahun) dengan Ketidaksiapan tersebut semakin diperlonggar dengan pengajuan adanya Pasal 3 Permenkumham No. 15 Tahun 2018, permohoan yang cenderung menegasikan Pasal 20 UU Paten 2016. kepada Menteri Jika UU Paten 2016 sebagaimana diatur dalam Pasal 173 
dengan disertai bahwa UU mulai berlaku pada saat diundangkan (26 alasan. Agustus 2016), maka ketentuan tersebut memberikan ruang kepada pemegang paten (khususnya luar negeri) untuk mengajukan penundaan paling lama 5 (lima) tahun. Penundaan inilah yang kemudian berpotensi merugikan atau setidak-tidaknya menghambat pembangunan negara Indonesia. Mengingat teknologi merupakan hal penting dan memberikan kontribusi dalam berbagai bidang, apalagi begitu cepatnya perkembangan teknologi.

Ketentuan penundaan tersebut juga tidak memberikan alasan yang definitif jika pemegang paten akan mengajukannya kepada Menteri. Ketidakjelasan aturan tersebut membuka ruang bagi Menteri dengan kewenangan yang melekat atas dasar subjektifitasnya. Menteri dapat "bermain mata" karena peraturannya tidak menentukan syarat atau pedoman untuk membatasi kewenangan tersebut. Peraturan Menteri yang merupakan peraturan pelaksanaan, seharusnya menentukan pengaturan secara rinci, termasuk alasan dan syarat-syarat penundaan pelaksanaan pembuatan produk atau menggunakan proses di Indonesia. Jika ketentuan setingkat Menteri masih sangat bersifat umum (general), maka tidak ada bedanya dengan peraturan setingkat UU.

Pengaturan yang tidak secara definitif menentukan alasan penundaan tentu bertentangan dengan salah satu tujuan hukum yakni kepastian (certainty). Hukum hadir selain memberikan kepastian, juga memberikan batasan-batasan yang diperbolehkan, serta hal-hal yang dilarang. Dalam konteks ini, hukum (Permenkumham No. 15 Tahun 2018) harus memberikan kepastian berupa alasan-alasan (kriteria) diperbolehkannya pengajuan penundaan pelaksanaan paten oleh pemegang paten. Pemberian kepastian alasan pada tataran implementasi relatif sulit diterapkan, apalagi jika tidak diberikan pengaturan. Hal ini berpotensi memengaruhi pencapaian semangat Indonesia untuk mandiri dalam penguasaan teknologi.

Keberatan-keberatan yang diajukan, terutama oleh pihak asing seharusnya bukan menjadi alasan untuk memberikan ruang yang longgar, karena memang TRIPs sebagai salah satu kesepakatan WTO memang atas keinginan negara-negara maju untuk memberikan pelindungan atas komoditi yang mereka miliki. 
Indonesia yang memiliki kedaulatan penuh harus berani menentukan batasan-batasan yang jelas dan memberikan ruang gerak yang sangat terbatas terhadap kemungkinan tidak dilaksanakannya kewajiban oleh pemegang paten.

4 Permohonan Formulasi pengaturan sebagaimana diatur Pasal 4 penundaan Permenkumham No. 15 Tahun 2018 memiliki sisi yang pelaksanaan relatif sangat lemah. Ketentuan tersebut sangat paling lama 3 membuka ruang tidak dilaksanakannya kewajiban (tiga) tahun sejak yang melekat kepada pemegang paten. Hal tersebut tanggal didasarkan bahwa permohonan penundaan hanya pemberian paten. diberikan waktu paling lama 3 (tiga) tahun sejak tanggal pemberian paten. Hal ini akan menjadi persoalan dengan paten yang telah memeroleh sertifikat lebih dari 3 (tiga) tahun. Padahal jauh sebelum diberlakukannya aturan ini juga tidak sedikit paten (terutama dari luar negeri) yang telah memeroleh sertifikat, tetapi belum dilaksanakan.

Formulasi pengaturan semacam ini menimbulkan pemegang paten tidak dapat dikenai kewajiban yang tertuang dalam UU Paten. Ketentuan ini dapat menghambat akselerasi penguasaan teknologi di Indonesia. Dari sisi tujuan hukum tentu tidak memberikan keadilan bagi semua pemegang paten, karena hanya diberlakukan bagi pemegang paten yang belum sampai 3 (tiga) tahun sejak mendapat sertifikat, padahal pelindungan paten diberikan sampai dengan 20 (dua puluh) tahun untuk paten biasa dan 10 (sepuluh) tahun untuk paten sederhana.

5 Dalam penundaan

hal Peraturan Menteri yang sifatnya lebih teknis, sudah disetujui seharusnya memberikan pengaturan yang lebih jelas Menteri, Permenkumham No. 15 Tahun 2018. Pasal 5 penundaan pelaksanaan Permenkumham No. 15 Tahun 2018 hanya menentukan paten bahwa dalam hal penundaan disetujui oleh Menteri, memberitahukan kepada maka Menteri akan memberitahukan kepada Pemegang Paten. pemegang paten. Ketentuan ini akan menjadi persoalan apabila permohonan tersebut tidak disetujui. Sebab, akan menjadi tidak jelas mengenai tanggung jawab Menteri untuk memberikan pemberitahuan. Padahal hukum seharusnya memberikan kejelasan, kepastian, keadilan dan kemanfaatan.

Sebaiknya peraturan ini juga disertai dengan ketentuan antisipatif, untuk mengatasi situasi apabila permohonan penundaan yang tidak disetujui oleh Menteri. Ketentuan dimaksud dapat berupa perintah 


\begin{tabular}{ll}
\hline & kepada pemohon untuk memperbaiki syarat/alasan \\
& permohonan (apabila persyaratan/kriteria alasan \\
& sudah diatur), atau diaturnya norma sanksi \\
& (administratif) kepada pemegang paten apabila tidak \\
& melaksanakan kewajiban sebagaiman diatur dalam \\
& peraturan perundang-undangan. \\
Penundaan & Paten sebagai salah satu jenis HKI memiliki limitasi \\
pelaksanaan & jangka waktu pelindungan hukum. Paten biasa berlaku \\
diperpanjang dapat & selama 20 (dua puluh) tahun dan paten sederhana selama \\
dengan disertai & Pasal 6 Permenkumham No. 15 Tahun 2018 masih \\
alasan. & membuka ruang perpanjangan waktu penundaan \\
& pelaksanaan paten dengan disertai alasan. Formulasi \\
& ketentuan ini relatif masih sangat lemah dan membuka \\
& ruang tidak dilaksanakannya kewajiban pelaksanaan \\
& paten sampai dengan habis masa pelindungannya. \\
& Limitasi pelindungan HKI yang berbatas, seharusnya \\
& diperhatikan dalam pengaturan ini, apalagi tidak \\
& disertainya ketentuan mengenai batas waktu \\
& perpanjangan penundaan. Bukan tidak mungkin \\
& penundaan pelaksanaan paten bersamaan dengan \\
pelindungan paten habis dan menjadi milik umum \\
(public domain). Pada akhirnya Indonesai tidak \\
mendapatkan apa-apa, baik alih teknologi, investasi, \\
maupun penyerapan tenaga kerja. Apalagi \\
perpanjangan dapat dilaksanakan dengan disertai \\
alasan. Tidak diaturnya alasan definitif mengenai \\
kriteria yang dapat dijadikan sebagai dasar pengajuan \\
dan pengabulan permohonan penundaan, sehingga \\
sangat membuka ruang bagi pemegang paten untuk \\
tidak melaksanakan kewajibannya. Dengan demikian, \\
tujuan hukum untuk memberikan kepastian akan \\
menjadi tiada guna (useless). \\
\hline
\end{tabular}

\section{Penutup}

Berdasarkan hasil analisis dan pembahasan di atas, dapat disimpulkan bahwa UU Paten 2016 dan Permenkumham No. 15 Tahun 2018 sebagai dasar hukum pelaksanaan kewajiban pemegang paten untuk membuat produk dan membuat proses di Indonesia ini masih mengandung sejumlah persoalan. Persoalan dimaksud antara lain adalah sumirnya beberapa ketentuan, yang dibuktikan dengan belum jelasnya waktu dimulainya pelaksanaan paten, lingkup dan jenis 
paten yang wajib dilaksanakan, pengaturan penundaan pelaksanaan yang tidak disertai dengan ketentuan berupa kriteria (alasan) mengenai dapat atau tidaknya dilakukan penundaan, pengaturan batas waktu pengajuan permohonan penundaan yang tidak memerhatikan durasi pelindungan paten, tidak adanya ketentuan antisipatif untuk mengatasi kondisi apabila permohonan penundaan tidak disetujui oleh Menteri, serta pengaturan perpanjangan penundaan yang tidak disertai dengan ketentuan batas waktu dan kriteria (alasan) dapat atau tidaknya dilakukan perpanjangan penundaan. Kesumiran pengaturan ini berpotensi menimbulkan celah hukum berupa tidak terlaksanakannya kewajiban tersebut. Selain itu juga akan berdampak pada tidak terwujudnya alih teknologi, penyerapan investasi, dan/atau penyediaan lapangan kerja di Indonesia.

Rekomendasi yang penulis tawarkan untuk mengatasi persoalan hukum ini adalah mengubah materi muatan Permenkumham No. 15 Tahun 2018 dengan memerhatikan analisis dan rekomendasi di atas, agar terwujud kepastian dan kemanfaatan dalam pengaturan paten di Indonesia. Secara lebih spesifik penulis mendorong perumusan peraturan mengenai waktu dimulainya pelaksanaan paten, lingkup dan jenis paten yang wajib dilaksanakan, pengaturan penundaan pelaksanaan yang disertai dengan kriteria (alasan) dapat atau tidaknya dilakukan penundaan, pengaturan batas waktu pengajuan permohonan penundaan yang memerhatikan durasi pelindungan paten, mengatur ketentuan antisipatif untuk mengatasi kondisi apabila permohonan penundaan tidak disetujui oleh Menteri, serta pengaturan perpanjangan penundaan yang disertai dengan batas waktu dan kriteria (alasan) dapat atau tidaknya dilakukan perpanjangan penundaan, serta perlu dipertimbangkannya pengaturan mengenai sanksi administratif bagi pemegang paten yang tidak melaksanakan kewajibannya.

\section{Daftar Pustaka}

\section{Buku}

Astutty Mochtar, Dewi, Perjanjian Lisensi Alih Teknologi dalam Pengembangan Teknologi Indonesia, Alumni, Bandung, 2001.

Hartono, Sri Redjeki, Kapita Selekta Hukum Ekonomi, Mandar Maju, Bandung, 2000. 
Idris, Kamil, Kekayaan Intelektual Sebuah Kekuatan Untuk Pertumbuhan Ekonomi, Direktorat Jenderal Hak Kekayaan Intelektual, Departemen Kehakiman dan Hak Asasi Manusia Republik Indonesia, Jakarta, 2000.

MD, Moh Mahfud, Membangun Politik Hukum, Menegakkan Konstitusi, Rajawali Pers, Jakarta, 2010.

Nurbaningsih, Enny, Naskah Akademik RUU tentang Paten, Badan Pembinaan Hukum Nasional, Jakarta, 2015.

Purwaningsih, Endang, Perkembangan Hukum Intellectual Property Right: Kajian Hukum terhadap Hak atas Kekayaan Intelektual dan Kajian Komparatif Hukum Paten, Ghalia Indonesia, Bogor, 2005.

Roisah, Kholis, Konsep Hukum Hak Kekayaan Intelektual (Sejarah, Pengertian, dan Filosofi HKI dari Masa ke Masa), Setara Press, Malang, 2015.

Saidin, OK, Aspek Hukum Hak Kekayaan Intelektual (Intellectual Property Right), Raja Grafindo Persada, Jakarta, 2013.

Samsudin, Dadang, Hak Kekayaan Intelektual dan Manfaatnya Bagi Lembaga Litbang, Direktorat Jenderal Kekayaan Intelektual Kementerian Hukum dan Hak Asasi Manusia, Jakarta, 2016.

Soemitro, Ronny Hanitijo, Metodologi Penelitian Hukum dan Jurimetri, Ghalia Indonesia, Jakarta, 1988.

Tampubolon, Sabartua, Politik Hukum Iptek di Indonesia, Kepel Press, Yogjakarta, 2013.

Utomo, Tomy Suryo, Hak Kekayaan Intelektual di Era Global, Graha Ilmu, Yogyakarta, 2010.

\section{Jurnal}

Fanny, Rindia, "Reformasi Peraturan Paten di Indonesia". SNH Seminar Nasional Hukum Universitas Negeri Semarang, 2(1): Vol. 2 No.1, 2016.

Gumanti, Retna, "Perjanjian Lisensi di Indonesia”, Jurnal Al Mizan IAIN Gorontalo, Vol. 12, 2016.

Purba, Achmad Zen Umar, "Peta Mutakhir Hak Kekayaan Intelektual di Indonesia", Jurnal Hukum dan Pembangunan, Vol. 26, 2002.

Purwaningsih, Endang. "Paten Sebagai Konstruksi Hukum Perlindungan Terhadap Invensi dalam Bidang Teknologi dan Industri", Jurnal Pro Justitia, Vol.24, No. 2, 2006.

Sitorus, Winner, "Kepentingan Umum dalam Perlindungan Paten", Yuridika, Vol. 29 No. 1, 2014.

\section{Internet}

"Akademisi FHUI Menilai Pasal 20 UU Paten Berguna Untuk Transfer Teknologi", https:/ / kliklegal.com/akademisi-fhui-menilai-pasal-20-uu-patenberguna-untuk-transfer-teknologi diakses tanggal 29 Mei 2019. 
"Ini Alasan DPR Wajibkan Pemegang Paten Membuat Produk di Indonesia". Available online from: https://kliklegal.com/ini-alasan-dpr-wajibkanpemegang-paten-membuat-produk-di-indonesia/, diakses pada tanggal 14 Mei 2019.

"Pemilik Paten Dari Luar Negeri Bisa Tunda Laksanakan Paten Indonesia", https://www.kk-advocates.com/wp-content/uploads/pemilik-patendari-luar-negeri-bisa-tunda-laksanakan-paten-indonesia.pdf Diakses 6 Agustus 2019.

“Wajibkan Pemegang Paten Membuat Produk di Indonesia, UU Paten Menuai Kritik", https://kliklegal.com/wajibkan-pemegang-paten-membuatproduk-di-indonesia-uu-paten-menuai-kritik/ Diakses tanggal 14 Mei 2019.

\section{Peraturan Perundang-Undangan}

Undang-Undang Nomor 6 Tahun 1989 Tentang Paten, Lembaran Negara Republik Indonesia Nomor 39 Tahun 1989, Tambahan Lembaran Negara Nomor 3398.

Undang-undang Nomor 7 Tahun 1994 tentang Pengesahan Agreement Establishing the World Trade Organization (Persetujuan Pembentukan Organisasi Perdagangan Dunia), Lembaran Negara Republik Indonesia Nomo 57 Tahun 1994, Tambahan Lembaran Negara Nomor 3564.

Undang-Undang Nomor 13 Tahun 1997 Tentang Perubahan Atas Undang-Undang Nomor 6 Tahun 1989 Tentang Paten, Lembaran Negara Republik Indonesia Nomor 30 Tahun 1997, Tambahan Lembaran Negara Nomor 3680.

Undang-Undang Nomor 14 Tahun 2001 Tentang Paten, Lembaran Negara Republik Indonesia Nomor109 Tahun 2001, Tambahan Lembaran Negara Nomor 4130.

Undang-Undang Nomor 12 Tahun 2011 Tentang Pembentukan Peraturan Perundang-Undanga, Lembaran Negara Republik Indonesia Nomor 82 Tahun 2011, Tambahan Lembaran Negara Nomor 5234.

Undang-Undang Nomor 13 Tahun 2016 Tentang Paten, Lembaran Negara Republik Indonesia Nomor 176 Tahun 2016, Tambahan Lembaran Negara Nomor 5922.

Peraturan Menteri Hukum dan Hak Asasi Manusia Nomor 15 Tahun 2018 Tentang Pelaksanaan Paten Oleh Pemegang Paten. 